\title{
Assessment of Water Quality of Peddacheruvu, Sambaiah Cheruvu, Gaddapotharam and Rudraram Cheruvu of Medak District
}

\author{
Saritha Poodari, Shankaraiah Golla, Bhagawan. D and Vurimindi Himabindu* \\ Center for Environment, Institute of Science and Technology,Jawaharlal Nehru Technological University, Hyderabad, India 500085
}

Received 15 June 2013; Accepted 23 February 2014

\begin{abstract}
In the present study, an attempt is made to analyze the physico-chemical aspects along with trace elements and organics of four different lake waters of the industrial area of Medak district namely - Gaddapotharam, Peddacheruvu, Sambaiah \& Rudraram cheruvu. The lake water analysis shows that among all the lakes, Gaddapotharam Lake is the highly polluted lake followed by Rudraram Lake. Peddacheruvu and Sambaiah lakes might be polluted due to rainwater/storm water discharges. The results clearly show that majority of water quality parameters such as Chemical Oxygen Demand, chlorides and dissolved solids are quite high. This might be due to the collection of samples in summer during which the pollutants might have got concentrated and hence the analysis results are observed to be high. The levels of pollutants are found to be high at the inlet areas of the lakes close to industrial area. In addition, high levels in some sites are also due to agricultural and sewage drainages of some villages. Moreover, it is also observed that during midsummer all the lakes have dried up except for Gaddapotharam Lake. The dry sediments can be removed by digging out and replacing the bottom with good soil cover which will support aquatic life of the clean water that may enter with rainfall.
\end{abstract}

Keywords: Assessment; Biomanipulation; Chemical oxygen demand; Dissolved oxygen; industrial effluents; lake restoration.

\section{Introduction}

Surface Water is a vital component of the environment and is a matter of serious concern today since the quality of surface water is rapidly deteriorating in many regions, and polluted surface water has become a grave public health and ecosystem problem [1].The quality of surface water has become a critical issue due to the concern that freshwater will be a scarce resource in the future [2]. Lakes, ponds and streams constitute fresh surface water habitats, which harbour aquatic life. With unprecedented developmental activities, human beings are responsible for choking several lakes to death. Storm water runoff, discharge of sewage and industrial effluents into the lakes are few of the common causes where various toxic compounds enter the aquatic ecosystems resulting in the deterioration of lake water quality [3]. This loss of water quality is causing health hazards, death of aquatic lives and crop failures. Under such conditions, the need to study and monitor the condition of lakes has become very critical. The ever-increasing importance and threat to long term sustainability of the lakes due to industrialization makes the present study highly relevant.

The objective of this study is, therefore to assess the quality of water in four lakes of Medak district, namely:

- Gaddapotharam

- Peddacheruvu

- Sambaiah cheruvu

\section{- Rudraram cheruvu}

In the present study, an attempt is made to analyze the physico-chemical aspects along with trace elements and organics of the lake water.

\subsection{Description of the study area}

Medak District with an area of $9702 \mathrm{~km}^{2}$ and lying between North Latitudes $17^{\circ} 27^{\prime} \& 18^{\circ} 18^{\prime}$ and $77^{\circ} 28^{\prime} \& 79^{\circ} 10^{\prime}$ East longitudes on the Northeastern part of Andhra Pradesh state, India, is presently experiencing a rapid industrial growth. This area was predominantly an agricultural land. The Patancheru Industrial Estate was set up in 1975 as part of government's initiative to bring in more industries and to industrialize the backward areas in the State of Andhra Pradesh, India. As a result, Medak has been transformed into an Industrial belt. During the development of these industrial estates, no effort was made by the industrial units to integrate environment management measures to prevent the adverse impacts of industrial discharges. There are a few or no mechanisms for the safe treatment and release of effluents. In fact, the industries have been deliberately disposing their wastes into the nearby land and water bodies.

Among all the places in Medak District, Gaddapotharam, Gomaram, Nawabpet and Rudraram villages are observed to be the potential zones of industrial pollution. The lakes in and around these villages are highly polluted and the industrial effluents are the major sources of pollution affecting the surface water as well as ground water.

1.1.1 Gaddapotharam cheruvu: It is located just South of Gaddapotharam village at a latitude of $17^{\circ} 35^{\prime}$ and $78^{\circ} 22^{\prime}$

\footnotetext{
*E-mail address: vurimindihimabindu@yahoo.com ISSN: 1791-2377 @ 2013 Kavala Institute of Technology. All rights reserved.
} 
longitude in Medak district. The total area of the lake (Fig 1Plate $1 \& 2$ ) is approximately $0.08 \mathrm{Km}^{2}$. The total catchment area of the Gaddapotharam village is $0.093 \mathrm{Km}^{2}$ (approximately). The main catchment - industrial area (with a total industrial area of $2.5 \mathrm{Km}^{2}$ approx.) is located towards the southeast side of the lake. The lake is fed by 2-3 minor channels or streams. Maximum depth of the lake is about 10 $\mathrm{ft}$.
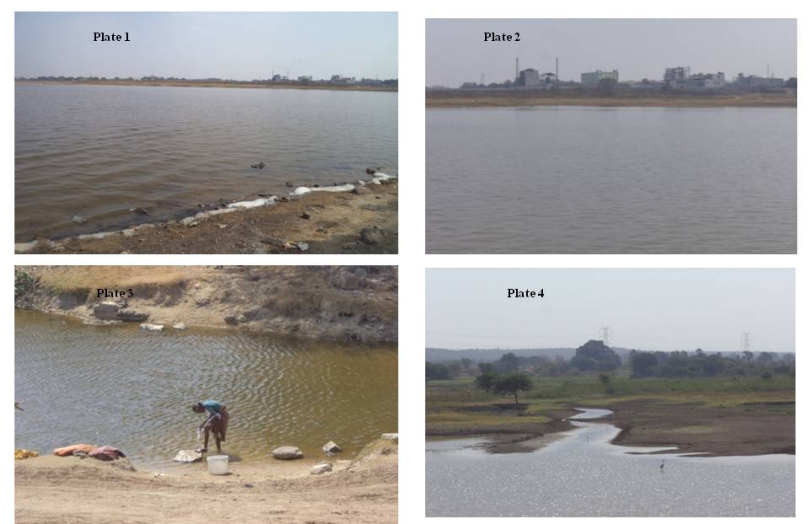

Fig. 1. Plate 1:Gaddapotharam Lake; Plate 2: Industries near Gaddapotharam Lake; Plate 3 Washing inlet to Peddacheruvu; Plate 4 Field inlet to Peddacheruvu

1.1.2 Pedda cheruvu: It is located at a latitude of $17^{\circ} 44^{\prime}$ and $78^{\circ} 23^{\prime}$ longitude with a total area of $0.077 \mathrm{Km}^{2}$ and a depth of $3 \mathrm{ft}$ approximately (Fig 1-Plate $3 \& 4$ ). Towards north of the lake is the Gomaram village with a total catchment area of $0.3 \mathrm{Km}^{2}$ approx. while agricultural fields occupying approximately $0.28 \mathrm{Km}^{2}$ of area exists towards the south of the lake. Industries are located towards the northeast of the lake.

1.1.3 Sambaiah cheruvu: It is located at a latitude of $17^{\circ} 43^{\prime}$ and $78^{\circ} 23^{\prime}$ longitude at an altitude of $2005 \mathrm{ft}$. The total area of the lake (Fig 2-Plate 5) approximates to almost $0.113 \mathrm{Km}^{2}$ and a depth of $3 \mathrm{ft}$. Towards northwest of the lake is the Nawabpet Village with a catchment area of approx. 0.163 $\mathrm{Km}^{2}$. Industries are located towards south of the lake at an altitude of $2125 \mathrm{ft}$.

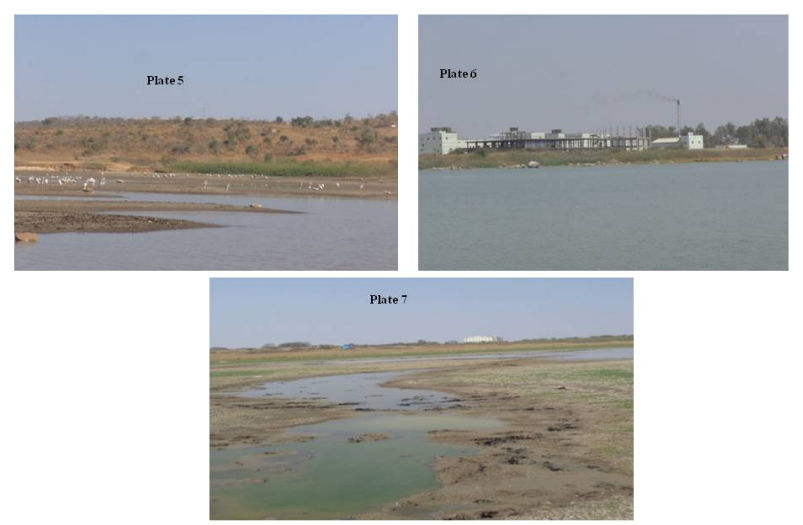

Fig. 2. Plate 5: Sambaiah Cheruvu with a number of birds; Plate 6:Industries at the North Eastern side of Rudraram cheruvu plate 7: Inlet at the South eastern side of Rudraram cheruvu with algae

1.1.4 Rudraram cheruvu: It is located at a latitude of $17^{\circ} 33^{\prime}$ and $78^{\circ} 10^{\prime}$ longitude. The total area of the lake is approximately $0.24 \mathrm{Km}^{2}$. The depth of the lake (Fig 2-Plate $6 \& 7$ ) is about $5 \mathrm{ft}$ approximately. Towards northwest of the lake is the Rudraram Village with a catchment area of about $0.47 \mathrm{Km}^{2}$ (approx.). Industries are located round the lake with a total area of about $0.71 \mathrm{Km}^{2}$ (approximately).

\section{Methodology}

\subsection{Sample collection \& preservation}

Surface water samples are collected from Gaddapotharam Lake, Peddacheruvu, Sambaiah cheruvu, and Rudraram cheruvu and some ground water samples from the surrounding areas in February 2012. Samples are collected in clean and dry plastic bottles. Water samples for trace metal analysis are preserved by adding concentrated nitric acid $(3 \mathrm{ml} / \mathrm{L})$.

\subsection{Sample analysis}

After collection, the samples are transported to the lab and analyzed for a number of physical, chemical and biological parameters according to standard methods (APHA $21^{\text {st }}$ edition, 1998). Trace metal analysis using AAS (Atomic absorption spectrometer) and Organic analysis using GC-MS in lake water and sediment samples is also done. Identification of organics in lake samples is done using GCMS and their presence is confirmed by $93-97 \%$ matching with NIST library search. A brief detail of the methods and equipment used in the study are given in Table 1.

Table 1. Physico-chemical and Analytical methods \& equipment used in the study

\begin{tabular}{|c|c|c|c|}
\hline S.No & Parameter & Method & Instrument/Equipment \\
\hline \multicolumn{4}{|c|}{ (A) Physico-chemical } \\
\hline 1 & $\mathrm{pH}$ & Electrometric & $\mathrm{pH}$ meter \\
\hline 2 & Conductivity & Electrometric & Conductivity meter \\
\hline 3 & TDS & Gravimetric & - \\
\hline 4 & Alkalinity & Titration by $\mathrm{H}_{2} \mathrm{SO}_{4}$ & - \\
\hline 5 & Total Hardness & Titration by EDTA & - \\
\hline 6 & Ca hardness & Titration by EDTA & - \\
\hline 7 & Mg hardness & Titration by EDTA & - \\
\hline 8 & Chlorides & Argentometric & - \\
\hline 9 & Sulphates & Turbidimetric & $\begin{array}{l}\text { UV-Visible } \\
\text { Spectrophotometer }\end{array}$ \\
\hline 10 & Phosphates & $\begin{array}{l}\text { Stannous chloride } \\
\text { method }\end{array}$ & $\begin{array}{l}\text { UV-Visible } \\
\text { Spectrophotometer }\end{array}$ \\
\hline 11 & Nitrates & $\begin{array}{l}\text { UV Spectrophotometric } \\
\text { screening }\end{array}$ & $\begin{array}{l}\text { UV-Visible } \\
\text { Spectrophotometer }\end{array}$ \\
\hline 12 & Nitrites & Colorimetric method & $\begin{array}{l}\text { UV-Visible } \\
\text { Spectrophotometer }\end{array}$ \\
\hline 13 & $\begin{array}{l}\text { Kjeldhal } \\
\text { ammonia }\end{array}$ & Kjeldhal method & Kjel plus \\
\hline 14. & $\begin{array}{l}\text { Kjeldhal } \\
\text { nitrogen }\end{array}$ & Kjeldhal method & Kjel plus \\
\hline 14 & Sodium & Flame emission & Flame photometer \\
\hline 15 & Potassium & Flame emission & Flame photometer \\
\hline 16 & Total COD & $\begin{array}{l}\text { Digestion followed by } \\
\text { titration using FAS }\end{array}$ & Reflux method \\
\hline 17 & Dissolved COD & $\begin{array}{l}\text { Digestion followed by } \\
\text { titration using FAS }\end{array}$ & Reflux method \\
\hline 18 & $\begin{array}{l}\text { Dissolved } \\
\text { Oxygen }\end{array}$ & Iodometric & - \\
\hline 19 & BOD & $\begin{array}{l}5 \text { days incubation } \\
\text { followed by titration }\end{array}$ & BOD incubator \\
\hline \multicolumn{4}{|c|}{ (B) Heavy Metals } \\
\hline $\begin{array}{l}1 \\
2 \\
3 \\
4 \\
5 \\
6 \\
7 \\
8 \\
9 \\
\end{array}$ & $\begin{array}{l}\text { Arsenic } \\
\text { Copper } \\
\text { Cadmium } \\
\text { Chromium } \\
\text { Lead } \\
\text { Iron } \\
\text { Manganese } \\
\text { Mercury } \\
\text { Zinc } \\
\end{array}$ & Digestion & $\begin{array}{l}\text { Atomic Absorption } \\
\text { Spectrometry }\end{array}$ \\
\hline (C) & Organics & $\begin{array}{l}\text { Gas-Chromatography } \\
\text { Mass spectrophotometry }\end{array}$ & GC-MS (Agilent 5660) \\
\hline
\end{tabular}

\subsection{Sampling points}

The point sources identified for the Gaddapotharam Lake are the industries located at the elevated side and the domestic sewage coming from the village located near to the lake. 
From each lake approximately 6-8 samples are collected at different locations (Table 2). For Peddacheruvu and Sambaiah cheruvu, nutrients from domestic and municipal wastewater are observed to be the main point sources. Storm water is also one of the point source for both these lakes since the industries are located very far but on an elevated side. The nonpoint sources observed are the nutrients through fertilizers, toxic pesticides and other chemicals, mainly from agriculture runoff and organic pollution from human settlements spread over the periphery of the lakes. In case of Rudraram Lake, the point sources observed are mainly the industries and the nonpoint source is the agricultural runoff. A point to be noted is that all the industries are on the elevated side and waters have natural tendency to flow towards the lake.

Table 2. Sampling points in the lakes

\begin{tabular}{|c|c|c|c|}
\hline No. & $\begin{array}{l}\text { Name of the } \\
\text { lake }\end{array}$ & Samples & Sampling site (Directions) \\
\hline \multirow[t]{6}{*}{1} & Gaddapotharam & 1 & Centre of the lake (surface) \\
\hline & & 2 & Centre of the lake (submerged) \\
\hline & & 3 & South West \\
\hline & & 4 & South East \\
\hline & & 5 & North East \\
\hline & & 6 & North \\
\hline \multirow[t]{7}{*}{2} & Peddacheruvu & 1 & North West \\
\hline & & 2 & South East \\
\hline & & 3 & South West \\
\hline & & 4 & South \\
\hline & & 5 & East \\
\hline & & 6 & Centre of the lake \\
\hline & & 7 & North \\
\hline \multirow[t]{5}{*}{3} & Sambaiah & 1 & West \\
\hline & & 2 & Centre of the lake \\
\hline & & 3 & South \\
\hline & & 4 & North West \\
\hline & & 5 & North \\
\hline \multirow[t]{6}{*}{4} & Rudraram & 1 & North East \\
\hline & & 2 & South East \\
\hline & & 3 & South \\
\hline & & 4 & North West \\
\hline & & 5 & North \\
\hline & & 6 & West \\
\hline
\end{tabular}

\section{Results \& Discussion}

The physicochemical characteristics of water and sediment samples collected from all the lakes have been studied for different parameters and the results of these analyses for each lake are discussed below in detail:

\subsection{Gaddapotharam Lake}

Six water samples have been collected from Gaddapotharam Lake and have been subjected to physicochemical analyses, the results of which are given in Table 3(A).

\subsubsection{Characteristics of Lake (Surface) water samples collected from Gaddapotharam Lake}

The $\mathrm{pH}$ of the water samples collected in the lake range from 8.0-8.3 and they are found to be within the permissible limits of USEPA \& WHO standards. Electrical conductivity (EC) of the lake water samples is observed to range from $7300-8796 \mu \mathrm{S} / \mathrm{cm}$.

The alkalinity of the lake water is in the range of 1900 $2325 \mathrm{mg} / \mathrm{l}$ with a maximum of $2325 \mathrm{mg} / \mathrm{l}$ of alkalinity found in sample-6 collected near the village inlet. Maximum alkalinity values might be attributed to the increase in the rate of organic decomposition resulting in the liberation of $\mathrm{CO}_{2}$, which reacts with water to form $\mathrm{HCO}_{3}{ }^{-}$, thereby increasing the total alkalinity $[4,5]$.
Table 3. Physicochemical, GC-MS \& Heavy Metal characteristics of the water samples collected from Gaddapotharam Lake

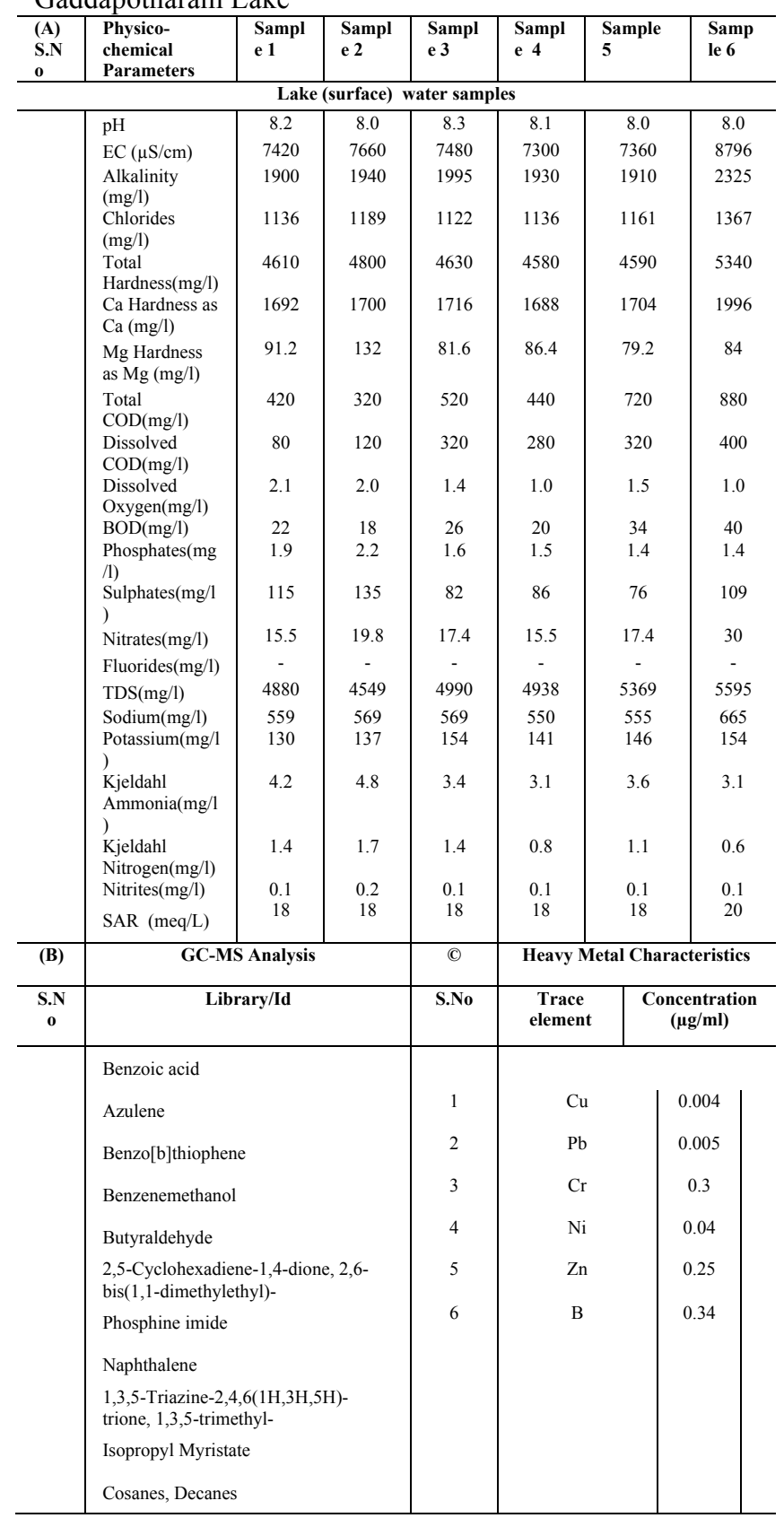

The COD content of the lake water is found to be between $320-880 \mathrm{mg} / \mathrm{L}$. COD of $320 \mathrm{mg} / 1$ is observed in sample-2 collected from the middle of the lake (at a depth of $1.5-2 \mathrm{~m}$ ) and $880 \mathrm{mg} / \mathrm{l}$ is observed in sample- 6 collected near the inlet point of the sewage water from village side. The findings of the present study indicate that, higher value of COD may be due to less water content and high turbid conditions. The higher turbidity shows the presence of higher concentration of organic and non-biodegradable components in the lake water which require higher amount of oxygen for their decomposition [6].

The BOD of the lake water is observed to be in the range of $18-40 \mathrm{mg} / \mathrm{l}$ with $18 \mathrm{mg} / \mathrm{l}$ at middle of the lake (submerged, sample-2) and $40 \mathrm{mg} / \mathrm{l}$ at village side (sample6 ). The higher value of BOD indicates maximum consumption of oxygen and higher pollution load [7]. 
The amount of chlorides is within a range of 1121$1366 \mathrm{mg} / \mathrm{l}$. The increase in chloride concentration may be due to the discharge of municipal and industrial wastes in to the lake as reported by Kant and Raina 1990[3].. The maximum chloride concentration $(1367 \mathrm{mg} / \mathrm{l})$ is found in sample-6 collected from the site near to the village, which could be due to mixing of organic matter, bathing activities, urination and wastes of animals. The industries surrounding the lake may also contribute to high concentration of chlorides in the sample.

High concentration of dissolved solids ranging from $4549-5595 \mathrm{mg} / 1$ is observed in the lake water samples. The study has indicated low dissolved oxygen levels ranging from 1.0-2.1 mg/l. The low level of DO is indicative of polluted nature of the water body [8]. The amount of phosphates is in the range of $1.4-2.2 \mathrm{mg} / \mathrm{l}$. The concentration of sulphates varied from $75-134 \mathrm{mg} / \mathrm{l}$.

In lake water samples, nitrogen concentration is found to be ranging between $1.4-1.6 \mathrm{mg} / \mathrm{l}$ while the amount of ammonia ranges between $3.0-4.8 \mathrm{mg} / \mathrm{l}$, which can be attributed to contamination of the lake with sewage/industrial effluents.

The presence of organics in the lake water samples is identified from GC-MS analysis (Table 3-B). Organics like benzoic acid, napthalene, benzothiophene, and saturated hydrocarbons like decanes, cosanes etc., indicate the contamination of lake water with residues of Tar and bulk drug industries. This might be due to the contamination of lake from the bulk drug industries located near the lake.

Heavy metal analysis is also done for lake water using Atomic Absorption Spectrophotometer. The concentration of heavy metals remained below toxic limits except for chromium with a concentration of $0.3 \mu \mathrm{g} / \mathrm{ml}$, which is above the standard limits. It might be due to some external contamination/pollution from some industry (Table 3-C).

\subsection{Pedda Cheruvu}

The $\mathrm{pH}$ of the surface water of Peddacheruvu is within the permissible limits of US-EPA and WHO standards (6.0-8.5). The conductivity in all the samples is ranging from 874$911 \mu \mathrm{S} / \mathrm{cm}$ except for the sample 2 , which is collected from the inlet near field side $(1550 \mu \mathrm{S} / \mathrm{cm})$ and sample 1 collected from washing inlet to cheruvu $(1361 \mu \mathrm{S} / \mathrm{cm})$.

The COD value fluctuated in the range of $280-380 \mathrm{mg} / 1$. The concentration of COD is found to be high (Table 4-A) in sample 2 collected near the inlet site $(1100 \mathrm{mg} / \mathrm{l})$, which might be due to the runoff of chemicals applied in the fields [9].

The dissolved oxygen content is $5.5 \mathrm{mg} / \mathrm{l}$ in the sample 1 , collected from washing inlet to cheruvu while in other samples collected from the lake it ranges from 1.5-2.9 mg/l.

The concentration of phosphates ranged from 1.0-3.8 $\mathrm{mg} / \mathrm{l}$. Samples $1 \& 2$ collected from washing inlet to cheruvu and inlet at the field site showed high concentration of phosphates $(3.8 \& 3.5 \mathrm{mg} / \mathrm{l})$ which might be due to the detergents used during washing at the washing inlet site and phosphate fertilizers added to the field inlet site [10].

The concentration of nitrates is observed to range from $6.2-8.6 \mathrm{mg} / \mathrm{l}$ while the concentration of ammonia is ranging from 1.1-8.9 mg/l. The high concentration of ammonia (8.9 $\mathrm{mg} / \mathrm{l})$ is observed in the sample 2 collected from the field inlet site may be due to the application of fertilizers to the field [11]. The sulphates ranged from $63-73 \mathrm{mg} / 1$.

The total alkalinity is varied from $200-425 \mathrm{mg} / \mathrm{l}$ while the amount of chlorides ranged from 117-192 mg/l. Samples $1 \& 2$ collected from washing inlet and field inlet showed high amounts of chloride (185 and $192 \mathrm{mg} / \mathrm{l})$ when compared to the other samples (range 117-122 mg/l).

Certain organic pollutants have also been observed in the lake (Table 4- B), which might be due to the runoff from agricultural fields near the lake or storm water discharge from industries. The lake is also characterized by the presence of heavy metals (Table 4-C). It is evident from the data that all elements studied are within the limits of International standards.

Table 4. Physicochemical, GC-MS \&Heavy metal characteristics of the water samples collected from Peddacheruvu

\begin{tabular}{|c|c|c|c|c|c|c|c|c|}
\hline $\begin{array}{l}\text { S.N } \\
\text { o } \\
\text { (A) }\end{array}$ & Parameter & $\begin{array}{l}\text { Samp } \\
\text { le } 1\end{array}$ & $\begin{array}{l}\text { Samp } \\
\text { le } 2\end{array}$ & $\begin{array}{l}\text { Samp } \\
\text { le } 3\end{array}$ & $\begin{array}{l}\text { Samp } \\
\text { le } 4\end{array}$ & $\begin{array}{l}\text { Samp } \\
\text { le } 5\end{array}$ & $\begin{array}{l}\text { Samp } \\
\text { le } 6\end{array}$ & $\begin{array}{l}\text { Samp } \\
\text { le } 7\end{array}$ \\
\hline 1 & $\mathrm{pH}$ & 8.3 & 8.2 & 8.4 & 8.3 & 8.4 & 8.3 & 8.3 \\
\hline 2 & $\mathrm{EC}(\mu \mathrm{S} / \mathrm{cm})$ & 1361 & 1550 & 911 & 897 & 923 & 874 & 905 \\
\hline 3 & $\begin{array}{l}\text { Alkalinity }(\mathrm{m} \\
\mathrm{g} / \mathrm{l})\end{array}$ & 340 & 425 & 215 & 205 & 215 & 200 & 220 \\
\hline 4 & $\begin{array}{l}\text { Chlorides(m } \\
\mathrm{g} / \mathrm{l})\end{array}$ & 185 & 192 & 121 & 117 & 117 & 121 & 122 \\
\hline 5 & $\begin{array}{l}\text { Total } \\
\text { Hardness(mg } \\
\text { /l) }\end{array}$ & 900 & 990 & 550 & 540 & 540 & 530 & 540 \\
\hline 6 & $\begin{array}{l}\text { Ca Hardness } \\
\text { as } \mathrm{Ca}(\mathrm{mg} / \mathrm{l})\end{array}$ & 260 & 324 & 168 & 164 & 168 & 164 & 176 \\
\hline 7 & $\begin{array}{l}\text { Mg Hardness } \\
\text { as } \mathrm{Mg}(\mathrm{mg} / \mathrm{l})\end{array}$ & & 43.2 & & 31.2 & & 28.8 & 36 \\
\hline 8 & $\begin{array}{l}\text { Total } \\
\text { COD }(\mathrm{mg} / \mathrm{l})\end{array}$ & 280 & 1100 & 360 & 320 & 340 & 380 & 320 \\
\hline 9 & $\begin{array}{l}\text { Dissolved } \\
\text { COD(mg/l) }\end{array}$ & 80 & 800 & 160 & 100 & 140 & 120 & 100 \\
\hline 10 & $\begin{array}{l}\text { Dissolved } \\
\text { Oxygen }(\mathrm{mg} / 1\end{array}$ & 5.5 & 2.9 & 2.2 & 2.5 & 2.3 & 1.5 & 1.9 \\
\hline 11 & $\mathrm{BOD}(\mathrm{mg} / \mathrm{l})$ & 12 & 36 & 14 & 38 & 34 & 10 & 12 \\
\hline 12 & $\begin{array}{l}\text { Phosphates( } \\
\mathrm{mg} / \mathrm{l})\end{array}$ & 3.8 & 3.5 & 1.1 & 1.0 & 1.2 & 1.0 & 1.2 \\
\hline 13 & $\begin{array}{l}\text { Sulphates(m } \\
\mathrm{g} / \mathrm{l})\end{array}$ & 68 & 73 & 63 & 64 & 67 & 65 & 68 \\
\hline 14 & Nitrates $(\mathrm{mg} / \mathrm{l}$ & 7.4 & 8.1 & 8.6 & 6.2 & 7.4 & 6.2 & 6.9 \\
\hline 15 & $\begin{array}{l}\text { Fluorides(mg } \\
\text { /l) }\end{array}$ & - & - & - & - & - & - & - \\
\hline 16 & $\mathrm{TDS}(\mathrm{mg} / \mathrm{l})$ & 909 & 995 & 569 & 574 & 594 & 554 & 571 \\
\hline 17 & $\begin{array}{l}\text { Sodium }(\mathrm{mg} / \mathrm{l} \\
\text { ) }\end{array}$ & 76 & 85 & 69 & 65 & 69 & 65 & 69 \\
\hline 18 & $\begin{array}{l}\text { Potassium(m } \\
\mathrm{g} / \mathrm{l})\end{array}$ & 58 & 70 & 27 & 24 & 28 & 29 & 23 \\
\hline 19 & $\begin{array}{l}\text { Kjeldahl } \\
\text { Ammonia(m } \\
\mathrm{g} / \mathrm{l})\end{array}$ & 2.8 & 8.9 & 1.7 & 1.1 & 1.4 & 1.4 & 1.1 \\
\hline 20 & $\begin{array}{l}\text { Kjeldahl } \\
\text { nitrogen(mg/ } \\
\text { 1) }\end{array}$ & 1.4 & 3.6 & 1.1 & 0.6 & 0.8 & 0.8 & 0.6 \\
\hline 21 & Nitrites $(\mathrm{mg} / \mathrm{l}$ & 0.03 & 0.1 & 0.02 & - & - & - & - \\
\hline 22 & SAR meq/L & 6.1 & 6.3 & 6.9 & 6.6 & 6.9 & 6.6 & 6.7 \\
\hline (B) & \multicolumn{3}{|c|}{ GC-MS Analysis } & (C) & \multicolumn{4}{|c|}{ Heavy metal characteristics } \\
\hline $\begin{array}{l}\text { S.N } \\
\text { o. }\end{array}$ & \multicolumn{3}{|l|}{ Library/Id } & S.No & \multicolumn{2}{|c|}{ Trace element } & \multicolumn{2}{|c|}{$\begin{array}{l}\begin{array}{l}\text { Concentration } \\
(\mu \mathrm{g} / \mathrm{ml})\end{array} \\
\end{array}$} \\
\hline & \multicolumn{3}{|c|}{ Benzyl Alcohol } & 1 & \multicolumn{2}{|l|}{$\mathrm{Cu}$} & \multicolumn{2}{|l|}{0.02} \\
\hline & \multicolumn{3}{|l|}{ Naphthalene } & 2 & \multicolumn{2}{|l|}{$\mathrm{Pb}$} & \multicolumn{2}{|l|}{0.008} \\
\hline & \multicolumn{3}{|l|}{ Cosanes } & 3 & \multicolumn{2}{|l|}{$\mathrm{Cr}$} & \multicolumn{2}{|l|}{0.05} \\
\hline & \multicolumn{3}{|l|}{ decanes } & 4 & \multicolumn{2}{|l|}{$\mathrm{Ni}$} & \multicolumn{2}{|l|}{0.013} \\
\hline & \multicolumn{3}{|c|}{ Diethyl Phthalate } & 5 & \multicolumn{2}{|l|}{$\mathrm{Zn}$} & \multicolumn{2}{|l|}{0.16} \\
\hline $\begin{array}{l}6 . \\
7 .\end{array}$ & \multicolumn{3}{|c|}{ 1,2-Benzenedicarboxylic acid } & 6 & \multicolumn{2}{|l|}{ B } & \multicolumn{2}{|l|}{0.04} \\
\hline
\end{tabular}

\subsection{Sambaiah Cheruvu}

A number of water samples are collected from Sambaiah cheruvu to check the water quality status of the lake. Table 5 (A) shows the physicochemical characteristics of the lake water. 
Saritha Poodari, Shankaraiah Golla, Bhagawan. D and Vurimindi Himabindu/

Journal of Engineering Science and Technology Review 7 (1) (2014) 137 - 142

Table 5. Physicochemical, GC-MS \& Heavy metal characteristics of the water samples collected from Sambaiah cheruvu

\begin{tabular}{|c|c|c|c|c|c|c|}
\hline $\begin{array}{l}\text { (A) } \\
\text { S.No }\end{array}$ & $\begin{array}{l}\text { Physico- } \\
\text { chemical } \\
\text { Parameter }\end{array}$ & $\begin{array}{l}\text { Sampl } \\
\text { e } 1\end{array}$ & $\begin{array}{l}\text { Sampl } \\
\text { e } 2\end{array}$ & $\begin{array}{l}\text { Sampl } \\
\text { e } 3\end{array}$ & $\begin{array}{l}\text { Sampl } \\
\text { e } 4\end{array}$ & $\begin{array}{l}\text { Sample } \\
5\end{array}$ \\
\hline 1. & $\mathrm{pH}$ & 8.3 & 8.4 & 8.5 & 8.8 & 8.9 \\
\hline 2. & $\mathrm{EC}(\mu \mathrm{S} / \mathrm{cm})$ & 920 & 874 & 1060 & 1072 & 1112 \\
\hline 3. & Alkalinity(mg/l) & 260 & 245 & 290 & 290 & 300 \\
\hline 4. & Chlorides(mg/l) & 89 & 82 & 117 & 121 & 124 \\
\hline 5. & $\begin{array}{l}\text { Total } \\
\text { hardness(mg/l) }\end{array}$ & 490 & 460 & 620 & 630 & 650 \\
\hline 6. & $\begin{array}{l}\mathrm{Ca} \text { Hardness as } \\
\mathrm{Ca}(\mathrm{mg} / \mathrm{l})\end{array}$ & 156 & 140 & 204 & 204 & 224 \\
\hline 7. & $\begin{array}{l}\mathrm{Mg} \mathrm{Hardness} \\
\text { asMg }(\mathrm{mg} / \mathrm{l})\end{array}$ & 24 & 26.4 & 26.4 & 28.8 & 21.6 \\
\hline 8. & $\begin{array}{l}\text { Total } \\
\text { COD(mg/l) }\end{array}$ & 560 & 480 & 760 & 400 & 960 \\
\hline 9. & $\begin{array}{l}\text { Dissolved } \\
\text { COD(mg/l) }\end{array}$ & 180 & 200 & 520 & 80 & 620 \\
\hline 10. & $\begin{array}{l}\text { Dissolved } \\
\text { Oxygen }(\mathrm{mg} / \mathrm{l})\end{array}$ & 2.6 & 1.9 & 0.8 & 2.4 & 1.7 \\
\hline 11. & $\mathrm{BOD}(\mathrm{mg} / \mathrm{l})$ & 16 & 14 & 40 & 12 & 45 \\
\hline 12. & Phosphates $(\mathrm{mg} / \mathrm{l}$ & 0.6 & 0.5 & 0.8 & 0.7 & 0.9 \\
\hline 13. & Sulphates(mg/l) & 67 & 60 & 65 & 66 & 67 \\
\hline 14. & Nitrates(mg/l) & 8.7 & 6.2 & 7.4 & 9.3 & 9.9 \\
\hline 15 . & Fluorides(mg/l) & - & - & - & - & - \\
\hline 16. & $\mathrm{TDS}(\mathrm{mg} / \mathrm{l})$ & 642 & 602 & 686 & 679 & 737 \\
\hline 17. & Sodium(mg/l) & 73 & 69 & 76 & 77 & 78 \\
\hline 18. & Potassium(mg/l) & 39 & 38 & 44 & 45 & 49 \\
\hline 19. & $\begin{array}{l}\text { Kjeldhal } \\
\text { Ammonia(mg/l) }\end{array}$ & 0.8 & 0.6 & 1.4 & 1.1 & 1.1 \\
\hline 20. & $\begin{array}{l}\text { Kjeldhal } \\
\text { Nitrogen(mg/l) }\end{array}$ & 0.3 & 0.3 & 0.8 & 0.6 & 0.8 \\
\hline 21. & Nitrites(mg/l) & - & - & 0.08 & 0.05 & 0.08 \\
\hline 22 . & SAR meq/L & 7.7 & 7.6 & 7.1 & 7.1 & 7.0 \\
\hline (B) & \multicolumn{2}{|c|}{ GC-MS analysis } & (C) & \multicolumn{3}{|c|}{ Heavy Metal Characteristics } \\
\hline S.No. & \multicolumn{2}{|c|}{ Library/Id } & S.No. & \multicolumn{2}{|c|}{\begin{tabular}{|l|l}
$\begin{array}{l}\text { Trace } \\
\text { element }\end{array}$ & \\
\end{tabular}} & $\begin{array}{l}\text { Concentratio } \\
\mathrm{n}(\mu \mathrm{g} / \mathrm{ml})\end{array}$ \\
\hline 1 & \multicolumn{2}{|l|}{ Naphthalene } & 1 & \multicolumn{2}{|l|}{$\mathrm{Cu}$} & 0.02 \\
\hline 2 & \multicolumn{2}{|l|}{ Tetradecane } & 2 & \multicolumn{2}{|l|}{$\mathrm{Pb}$} & 0.01 \\
\hline 3 & \multicolumn{2}{|l|}{ Benzaldehyde } & 3 & \multicolumn{2}{|l|}{$\mathrm{Cr}$} & 0.2 \\
\hline 4 & \multicolumn{2}{|l|}{ Pentadecane } & 4 & \multicolumn{2}{|l|}{$\mathrm{Ni}$} & 0.02 \\
\hline 5 & \multirow{2}{*}{\multicolumn{2}{|c|}{ Heptadecane }} & 5 & $\mathrm{Zn}$ & \multicolumn{2}{|c|}{0.06} \\
\hline & & & 6 & B & & \\
\hline
\end{tabular}

$\mathrm{pH}$ of the samples is within the limits except in samples $4 \& 5$ collected from outlets where the $\mathrm{pH}$ is slightly above the standard range i.e., 8.8 in sample 4 and 8.9 in sample 5 .

Dissolved Oxygen in water is of great importance to all aquatic organisms and is considered to be the factor that reflects the biological activity taking place in a water body and determines the biological changes [12]. The dissolved oxygen is found to be very low in sample $3(0.8 \mathrm{mg} / \mathrm{l})$ when compared to other samples since it is nearer to agricultural fields where the lake gets contaminated from the agricultural runoff.

The total COD is high in all the lake samples. However, sample 3 collected from the inlet and sample 5 collected from the out let showed high COD content of about 760 and $960 \mathrm{mg} / 1$ respectively. The high COD content at outlet might be due to accumulation of organics as there will be reduced flow of lake water (since the sample is collected in the dry season) [13]. The amount of nitrates, nitrites, ammonia and nitrogen are all within the permissible limits. However, the amount seems to be high in sample 3 collected from inlet compared to all other samples.

The quantities of organics present in the lake water are given in table 5 (B). A few organics are recorded in the lake water include benzaldehyde, naphthalene and decanes. This indicates that a very slight contamination is present in the lake which might be due to storm water discharge or agricultural runoff.

The concentrations of metals measured in the water samples collected from Sambaiah cheruvu are given in table 5 (C). All the metals are within the permissible limits. The concentration of lead is consistently below the detection levels $(0.01 \mu \mathrm{g} / \mathrm{ml})$.

\subsection{Rudraram Cheruvu}

The results of the physicochemical parameters in Rudraram Lake are given in table 6 (A). The $\mathrm{pH}$ of the samples is highly alkaline with $\mathrm{pH}$ ranging from 9.2-9.7 indicating abnormal condition due to industrial contamination. Electrical conductivity ranged from $3500-3900 \mu \mathrm{S} / \mathrm{cm}$. The chloride values are between $400-550 \mathrm{mg} / 1$ in the samples collected from the lake.

Table 6. Physicochemical, GC-MS \& Heavy metal characteristics of the water samples collected from Rudraram cheruvu

\begin{tabular}{|c|c|c|c|c|c|c|c|}
\hline $\begin{array}{c}\text { S.N } \\
\text { o }\end{array}$ & Parameter & $\begin{array}{l}\text { Samp } \\
\text { le 1 }\end{array}$ & $\begin{array}{l}\text { Samp } \\
\text { le 2 }\end{array}$ & $\begin{array}{l}\text { Samp } \\
\text { le } 3\end{array}$ & $\begin{array}{l}\text { Samp } \\
\text { le } 4\end{array}$ & $\begin{array}{l}\text { Samp } \\
\text { le 5 }\end{array}$ & Sample 6 \\
\hline & $\mathrm{pH}$ & 9.2 & 9.7 & 9.7 & 9.5 & 9.7 & 9.3 \\
\hline & $\mathrm{EC}(\mu \mathrm{S} / \mathrm{cm})$ & 3533 & 3719 & 3938 & 3782 & 3976 & 3897 \\
\hline & $\begin{array}{l}\text { Alkalinity(mg } \\
\text { /l) }\end{array}$ & 1030 & 1040 & 1055 & 1045 & 1090 & 1050 \\
\hline & $\begin{array}{l}\text { Chlorides(mg/ } \\
\text { l) }\end{array}$ & $\begin{array}{l}436.6 \\
5\end{array}$ & $\begin{array}{l}450.8 \\
5\end{array}$ & $\begin{array}{l}543.1 \\
5\end{array}$ & $\begin{array}{l}521.8 \\
5\end{array}$ & 539.6 & 536.05 \\
\hline & $\begin{array}{l}\text { Total } \\
\text { Hardness(mg/ } \\
\text { l) }\end{array}$ & 2110 & 2230 & 2270 & 2240 & 2310 & 2250 \\
\hline & $\begin{array}{l}\text { Ca Hardness } \\
\text { as } \mathrm{Ca}(\mathrm{mg} / \mathrm{l})\end{array}$ & 732 & 740 & 772 & 764 & 784 & 768 \\
\hline & $\begin{array}{l}\text { Mg Hardness } \\
\text { as Mg(mg/l) }\end{array}$ & 60 & 91.2 & 81.6 & 79.2 & 84 & 79.2 \\
\hline & $\begin{array}{l}\text { Total } \\
\text { COD(mg/l) }\end{array}$ & 840 & 600 & 580 & 720 & 640 & 680 \\
\hline & $\begin{array}{l}\text { Dissolved } \\
\text { COD }(\mathrm{mg} / \mathrm{l})\end{array}$ & 460 & 360 & 440 & 280 & 400 & 240 \\
\hline & $\begin{array}{l}\text { Dissolved } \\
\text { Oxygen }(\mathrm{mg} / \mathrm{l})\end{array}$ & 2.1 & 1.5 & 1.5 & 1.0 & 1.2 & 1.5 \\
\hline & $\mathrm{BOD}(\mathrm{mg} / \mathrm{l})$ & 26 & 20 & 15 & 30 & 25 & 30 \\
\hline & $\begin{array}{l}\text { Phosphates(m } \\
\mathrm{g} / \mathrm{l})\end{array}$ & 1.5 & 1.3 & 1.8 & 1.6 & 1.8 & 1.7 \\
\hline & $\begin{array}{l}\text { Sulphates }(\mathrm{mg} / \\
\text { l) }\end{array}$ & 100.3 & 105.6 & 96 & 83.5 & 103.2 & 92.6 \\
\hline & Nitrates(mg/l) & 29.1 & 34.1 & 29.8 & 29.1 & 28.5 & 28.5 \\
\hline & $\begin{array}{l}\text { Fluorides(mg/ } \\
\text { l) }\end{array}$ & - & - & - & - & - & - \\
\hline & $\mathrm{TDS}(\mathrm{mg} / \mathrm{l})$ & 2518 & 2488 & 2560 & 2532 & 2579 & 2578 \\
\hline & Sodium(mg/l) & 254.9 & 267.5 & 301.5 & 292.7 & 306.2 & 302.4 \\
\hline & $\begin{array}{l}\text { Potassium(mg } \\
\text { /l) } \\
\text { Kjeldahl }\end{array}$ & 121.7 & 125.9 & 125.9 & 82.7 & 135.7 & 121.7 \\
\hline & $\begin{array}{l}\text { Ammonia(mg } \\
\text { /l) } \\
\text { Kjeldahl }\end{array}$ & 2.8 & 2.5 & 3.4 & 4.8 & 4.2 & 3.1 \\
\hline & Nitrogen $(\mathrm{mg} / \mathrm{l}$ & 0.84 & 0.56 & 0.56 & 0.84 & 1.12 & 0.84 \\
\hline & Nitrite(mg/l) & 0.1 & 0.08 & 0.11 & 0.2 & 0.19 & 0.1 \\
\hline & SAR (meq/l) & 12.8 & 13.6 & 14.6 & 14.3 & 14.7 & 14.7 \\
\hline (B) & \multicolumn{3}{|c|}{ GC-MS analysis } & (C) & \multicolumn{3}{|c|}{ Heavy Metal Characteristics } \\
\hline $\begin{array}{l}\text { S.N } \\
\text { o. }\end{array}$ & \multicolumn{3}{|c|}{ Library/Id } & S.No. & \multicolumn{2}{|c|}{ Trace element } & $\begin{array}{l}\text { Concentrati } \\
\text { on }(\mu \mathrm{g} / \mathrm{ml})\end{array}$ \\
\hline & \multicolumn{3}{|l|}{ Benzyl Alcohol } & 1 & \multicolumn{2}{|l|}{$\mathrm{Cu}$} & 0.04 \\
\hline & \multicolumn{3}{|c|}{ Tetradecane, 2,6,10-trimethyl } & 2 & \multicolumn{2}{|l|}{$\mathrm{Pb}$} & 0.008 \\
\hline & \multicolumn{3}{|l|}{ Phosphine imide } & 3 & \multicolumn{2}{|l|}{$\mathrm{Cr}$} & 0.25 \\
\hline & \multicolumn{3}{|c|}{ Methoxyacetic acid, 2-tridecyl ester } & 4 & \multicolumn{2}{|l|}{$\mathrm{Ni}$} & 0.03 \\
\hline & \multicolumn{3}{|c|}{ Phenol, 2,4-bis(1,1-dimethylethyl) } & 5 & \multicolumn{2}{|l|}{$\mathrm{Zn}$} & 0.34 \\
\hline & \multicolumn{3}{|c|}{$\begin{array}{l}\text { 1,2-Benzenedicarboxylic acid } \\
\text { Decanes }\end{array}$} & 6 & \multicolumn{2}{|l|}{ B } & 0.56 \\
\hline
\end{tabular}

The dissolved oxygen levels are in the range of 1.0$2.1 \mathrm{mg} / \mathrm{l}$. The low level of DO is again indicative of contaminated nature of water body [13]. The BOD of the lake water is between $20-30 \mathrm{mg} / \mathrm{l}$. The nitrate content of the lake water ranged between $28-34 \mathrm{mg} / \mathrm{l}$ while the nitrite 
content ranged between 0.1-0.2 mg/l. Significant sources of nitrates are fertilizers, decayed vegetable and animal matter, domestic and industrial effluents and atmospheric washouts. Unpolluted natural water contains usually only minute amounts of nitrate [5]. The phosphate value varied from 1.3$1.8 \mathrm{mg} / \mathrm{l}$. The US Environmental Protection Agency (1976) suggested that $0.08 \mathrm{mg} / \mathrm{l}$ of phosphate as the critical level for the occurrence of eutrophication in lakes and reservoirs. High amounts of total dissolved solids are observed in Rudraram Lake with the concentration ranging from 2488$2578 \mathrm{mg} / 1$.

A number of organics are identified in the lake water, the details of which are given in table 6 (B). Benzyl alcohol, quinoline, decane, cosanes, and benzene dicarbocyclic acid are some of the organics commonly observed in Rudraram lake water.

All the heavy metals analyzed in lake water are found to be within permissible limits except for chromium $(0.25 \mu \mathrm{g} / \mathrm{ml})$ (Table 6-C).

\section{Conclusions}

In the present study, the sampling is done on one occasion and it is very difficult to draw final conclusions. Water quality results of the four water bodies studied in and around Medak district are quite high to moderate. The results clearly show that majority of water quality parameters such as
COD, chlorides and dissolved solids are quite high. The levels of pollutants are found to be high at the inlet areas of the lakes close to industrial area. In addition, high levels in some sites are also due to agricultural and sewage drainages of some villages. Priority organic pollutants detected in the lake are phenols, phthalates and benzene compounds. Among all the studied lakes, Gaddapotharam Lake appears to be the highly contaminated. Fish mortality observed during sampling in Peddacheruvu and Sambaiah cheruvu may be due to the low levels of water (sampling done in dry season), low DO and high dissolved solids. High concentration of nitrates and phosphates and very good algal growth in Rudraram Lake is indicative of its eutrophic condition. As the sampling is done only on one occasion, it is not possible to arrive at authentic conclusions. Hence, it is desirable to collect data at least for a year to cover all the seasons to find out the fluctuations in different parameters which will definitely help in getting a comprehensive picture of lake ecology.

\section{Acknowledgement}

The author would like to thank Andhra Pradesh Pollution Control Board (APPCB) for funding this project and also Council of Scientific \& Industrial Research (CSIR), Government of India for providing the research fellowship (09/568(0053)/2012EMRI).

\section{References}

[1] Wu. J.Y, Mar. Pollut. Bull. 50, 1661-1667(2005)

[2] Pesce, S. F., \& Wunderlin, D. A, Water Research, 34, 2915 2926(2000).

[3] Kant, S. and A.K. Raina. J. Env. Biol., 11(2), 137 (1990).

[4] Chandrasekhar, S.V.A and Hakcel. M, Poll.Res., 27 (1), 185187(2008).

[5] S.E. Shinde.; T,S, Pathan.; K,S, Raut and D.L. Sonawane, Journal of Scientific Research, 8 (3), 544-554(2011).

[6] Rajiv Sharma and Ajay Capoor, World Applied Sciences Journal, 8 (1), 129-132(2010).

[7] Devaraju.; T.M. Venkatesha and P. Singh, Nature Env.and Poll. Tech., 4(2), 287-290(2005).
[8] Iqbal. P.J.; Pandit. A.K. and Javeed, J.A, Kashmir. , 6, 8185(2006).

[9] Manssour, $\mathrm{K}$ and B.A-Mufti, Jordan Journal of Civil Engineering, 4(4), 351-366(2010).

[10] Aggarwal, T.R.; K.N.Singh and A.K.Gupta, Pollution Research, 19(3), 491-494 (2000).

[11] Tiwari. M, Eco. Env. and Cons., 11(3-4), 491-4932005(2005).

[12] Medudhula.Thirupathaiah.; Ch,Samatha.; Chintha Sammaiah, International J. of Environmental Sciences, 3 (1), 172-180 (2012).

[13] Yeole, S.M. and G.P. Patil, J. of Aqua. Biol., 20(1), 41-44(2005).

[14] Sankar Narayan Sinha and Mrinal Biswas, Asian J. Exp. Biol. Sci., 2(1), 18-22(2011) 